\title{
Á beira do tumulo $\left(^{*}\right)$
}

\section{Gabriel de Rezende Filho}

Querido mestre.

E' com o coraçáo opresso pela dor que o vosso desaparecimento lhes trouxe, que à beira desta sepultura se reunem os vossos amigos e colegas para vos trazerem o seu comovido adeus!

Aqui estamos para render-vos a nossa última homenagem.

Impossivel seria - e nem a necessária serenidade teríamos - impossivel seria traçar neste momento o panegírico de Francisco Morato, estudando-lhe a personalidade de escól e realçando condignamente a sua intensa e multiforme vida de trabalho fecundo.

Consignemos, entretanto, que a sua inteligência fulgurante, a valiosa cultura filosófica e jurídica que possuia, levaram-no às culminâncias da intelectualidade de nossa gente, como legítimo expoente da cultura juridica nacional.

Advogado de alta reputação e justo renome pela firmeza e nobreza de atitudes, lutou sempre como verdadeiro apóstolo e combatente de primeira linha em pról da causa do direito e da justiça.

Pelejou ainda o bom combate do bem, servindo os ideais democráticos com inexcedivel bravura, civismo e dedicação.

(*) Discurso proferido por ocasião do sepultamento do prof. Francisco Morato. 
O seu prestigiado nome, entretanto, maior fulgor adquiriu dentro dos muros da velha Academia de Direito, onde a sua atuação, durante cinco lustros, foi das mais notaveis e eficientes.

Sabemos todos quantos a seu lado convivemos, das suas admiraveis preleções como catedrático de Direito Processual Civil, não se deixando fascinar pela gloriola dos improvisadores, antes cuidando carinhosamente do preparo das lições, notaveis pela profundeza dos conceitos, segurança da doutrina e acêrto das criticas e invariavelmente vasadas em apurada e escorreita forma.

E' que Francisco Morato manejava o vernáculo com destreza e superioridade e, daí, a gentileza e o donaire do fraseado, a beleza dos periodos, cheios de graça e de vida, dando expressão própria aos seus trabalhos acadêmicos, aos seus discursos parlamentares e às suas autorizadas monografias.

Diretor da Faculdade, posto em que, durante largo periodo, dificil e acidentado, prestou relevantes serviços, foi guia seguro da mocidade acadêmica, que se habituou a admirá-lo e respeitá-lo.

Formosa inteligência, vasta cultura juridica, alicerçada em profundos conhecimentos filosóficos, carater sem jaça, acendrado patriotismo, nobreza de atitudes, persistencia e uniformidade de dons e virtudes, numa linha sempre igual de retidão - eis, rapidamente, o conjunto de qualidades que exornaram a personalidade de Francisco Morato.

Foi, pois, com inteira justiça que a Congregação da Faculdade resolveu conferir-lhe — e o fez pela primeira vez - o nobilitante título de professor emérito, consagrando públicamente os seus indiscutiveis méritos e coroando esplendidamente a sua brilhante carreira universitária.

E o interêsse de Francisco Morato pela nośsa Casa continuou sempre o mesmo depois de sua aposentação, ali retornando muitas vezes em sessões de Congregação e festas acadêmicas. 
Ainda recentemente, em março dêste ano, proferiu eloquente oração, inaugurando o curso jurídico, com o aprumo e a autoridade de sempre, deleitando a quantos tiveram a fortuna de ouví-lo.

Baixais agora, querido mestre, à última morada, onde ides fruir o merecido repouso pela longa e fecunda vida que tivestes.

Nas paragens infinitas a que subiu a vossa alma de cristão, amparada pela fé, Deus há de recompensar-vos pela bondade de vosso espírito e pela prática das virtudes que exornam o verdadeiro crente.

Na lembrança e na saudade dos vossos colegas a vossa fronte cingiu-se de uma auréola, pois a vossa individualidade pujante brilhará sempre na nossa memória pelos exemplos que destes e pelos serviços prestados à Casa comum, a cujas tradições venerandas estais definitivamente incorporado.

Recebei, querido mestre, a sincera e comovida homenagem e o preito de saudade dos vossos colegas de Congregação. 